\title{
Pengaruh Kompetensi, Independensi dan Objektivitas terhadap Kualitas Audit (Studi Empiris pada Badan Pemeriksa Keuangan (BPK) RI Perwakilan Provinsi Sumatera Selatan)
}

\author{
Fenty Astrina ${ }^{1}$,Rosalina Ghazali ${ }^{2}$, Darmayanti ${ }^{3}$, Nurul Hutami Ningsih ${ }^{4}$, Jakaria \\ Mukholih $^{5}$, \\ ${ }^{1}$ Akuntansi,Fakultas Ekonomi dan Bisnis UM. Palembang, fentyasterina1@gmail.com \\ ${ }^{2}$ Akuntansi,Fakultas Ekonomi dan Bisnis UM. Palembang, rosalinaghozali1@gmail.com \\ ${ }^{3}$ Akuntansi,Fakultas Ekonomi dan Bisnis UM. Palembang, darmayanti@um-palembang.ac.id \\ ${ }^{4}$ Akuntansi, Fakultas Ekonomi dan Bisnis UM. Palembang, nurulhutaminingsih@ymail.com \\ ${ }^{5}$ Akuntansi, Fakultas Ekonomi dan Bisnis UM. Palembang, zakariamuholik388@ gmail.com
}

\begin{abstract}
ABSTRAK
Penelitian ini bertujuan untuk mengetahui pengaruh kompetensi, independensi dan objektivitas terhadap kualitas audit pada Badan Pemeriksa Keuangan Provinsi Sumatera Selatan. Populasi yang digunakan dalam penelitian ini adalah 35 auditor yang bekerja di Badan Pemeriksa Keuangan (BPK) Teknik analisis data yang digunakan adalah analisis regresi linier berganda dengan menggunakan program statistical program for specience (SPSS). Hasil penelitian ini menujukkan bahwa secara bersama variabel kompetensi, independensi dan objektivitas berpengaruh signifikan terhadap kualitas audit. Hal ini menunjukkan bahwa semakin tinggi kompetensi, independensi dan objektivitas yang dimiliki oleh seorang auditor maka akan semakin tinggi pula kualitas audit. Secara parsial variabel kompetensi berpengaruh negatif dan signifikan terhadap kualitas audit. Hal ini menunjukkan bahwa semakin rendah kompetensi yang dimiliki oleh seorang auditor maka akan semakin rendah pula kualitas audit. Sedangkan variabel independensi dan objektivitas berpengaruh signifikan terhadap kualitas audit. Hal ini menunjukkan bahwa semakin tinggi independensi dan objektivitas yang dimiliki oleh seorang auditor maka akan semakin tinggi pula kualitas audit yang dihasilkan.
\end{abstract}

Kata Kunci : Pengaruh Kompetensi, Independensi, Objektivitas, Kualitas Audit

\section{ABSTRACT}

This study aims to determine the effect of competence, independence and objectivity on audit quality at the financial audit agency of South Sumatra Province. The population used in this study was 35 auditors who worked in the Financial Audit Agency of South Sumatra province. The data analysis this study is multiple linear regression analysis, using the software program SPSS for Windows. The results of this study indicate that the variables of competence, independence and objectivity have a significant effect on audit quality. This shows that the higher the competence, independence and objectivity of an auditor, the higher the audit quality. Partially, the competency variable has a negative and significant effect on audit quality. This shows that the lower the competence possessed by an auditor, the lower the audit quality While the variables of independence and objectivity have a significant effect on audit quality. This shows that the higher the independence and objectivity of an auditor, the higher the audit quality

Keywords: Effect of Competence, Independence,Objectivity, Audit Quality.

\section{A. PENDAHULUAN}

Laporan keuangan sangat penting untuk memperoleh informasi sehubungan dengan posisi keuangan dari hasil operasi yang telah dicapai oleh suatu perusahaan. untuk menentukan apakah laporan keuangan tersebut disajikan secara wajar, dalam semua hal yang material, posisi keuangan dan hasil usaha perusahaan atau 
organisasi tersebut, maka diperlukan pemeriksaan (examination) yang dilakukan oleh auditor independen secara objektif atas laporan keuangan tersebut dengan tujuan untuk menilai kewajaran informasi yang tercantum dalam laporan keuangan (Mulyadi, 2016)

Opini audit yang diberikan olwh auditor harus memberikan keyakinan memadai bagi pemangku kepentingan mengenai laporan keuangan perusahaan klien tentang keandalan laporan keuangan (Ardianingsih, 2018), Oleh karena itu setiap auditor harus memiliki sifat kompeten dalam melakukan audit. (Tandiontong, 2016). Kompetensi seorang auditor yaitu memiliki pengetahuan, pelatihan keterampilan dan pengalaman yang memadai agar dapat menyelesaikan pekerjaan auditnya. Berdasarkan Standar Pemeriksaan Keuangan Negara (SPKN) (BPK-RI, 2017)menyebutkan auditor harus memiliki kompetensi profesional yang memadai untuk melaksanakan tugas pemeriksaan. Kompetensi profesional tersebut dibuktikan dengan sertifikat profesional yang diterbitkan oleh lembaga yang berwenang atau dokumen lainnya yang menyatakan keahlian. dalam penggunaan tenaga ahli, BPK harus meyakini bah/?wa tenaga ahli tersebut independen, memenuhi kualifikasi, kompeten dalam bidangnya, dan harus mendokumentasikan keyakinan tersebut.

Permasalah yang berkaitan dengan kompetensi dikemukakan oleh (IAPI, 2019) menyatakan kekecewaanya atas nama-nama yang lolos dari hasil seleksi tahap awal yang dilakukan Dewan Perwakilan Rakyat untuk maju sebagai calon anggota Badan Pemeriksa Keuangan atau_BPK periode 2019-2024. Kekecewaan ini lantaran tidak ada satupun calon yang lolos memiliki bukti kompetensi sebagai auditor.

Auditor juga harus memiliki sikap independen dalam menjalan tugasnya. Berdasarkan Standar Pemeriksaan Keuangan Negara (SPKN) (BPK-RI, 2017) Menyatakan bahwa Independensi adalah suatu sikap dan tindakan dalam melaksanakan pemeriksaan untuk tidak memihak siapapun dan tidak dipengaruhi oleh siapapun. auditor tidak hanya harus independen dalam fakta, tetapi juga harus independen dalam penampilan. Independensi dalam fakta (independence in fact) akan ada apabila pada kenyataannya auditor mampu mempertahankan sikap yang tidak memihak sepanjang pelaksanaan auditnya, sedangkan independensi dalam penampilan (independence in appearance) adalah pandangan pihak lain terhadap diri auditor sehubungan dengan pelaksanaan audit.

Independensi auditor merupakan dasar yang ada distruktur filosofiprofesi.Independensi sangat diperlukan oleh auditor karena, akibat kurangnya independensi auditor dan maraknya rekayasa laporan keuangan perusahaan atau organisasi, telah menurunkan kepercayaan para pemakai laporan keuangan auditan, seperti investor dan kreditor yang mempertanyakan eksistensi akuntan publik sebagai pihak yang independen .

Permasalahan yang berkaitan dengan independensi dikemukakan oleh Kuasa hukum Sjamsul Nurasalim, (Hasibuan, 2019) menyebut audit Badan Pemeriksa Keuangan (BPK) terkait penerbitan Surat Keterangan Lunas Bantuan Likuiditas Bank Indonesia (SKL BLBI) tidak independen. "Para tergugat dalam pelaksanaan audit atau pemeriksaan telah membatasi hanya menggunakan informasi atau bukti dari satu sumber saja, yaitu dari penyidik KPK yang jelas-jelas hanya berkepentingan untuk membuktikan tuduhannya," Ini menunjukkan para tergugat telah bersikap memihak atau dipandang memihak, tidak independen.

Sikap yang juga harus dimiliki oleh auditor yaitu Objektivitas, menurut Standar Pemeriksaan Keuangan Negara (SPKN) (BPK-RI, 2017), Objektivitas merupakan 
suatu sikap atau tindakan untuk tidak memihak dan bebas dari benturan kepentingan dalam menjalankan tugasnya.

Permasalahan serupa yang berkaitan dengan objektivitas masih dikemukakan oleh (Hasibuan, 2019) menyebut pemeriksaan wajib dilakukan secara objektif yang terlihat dari penyajian laporan audit yang secara seimbang membahas pandangan, informasi atau bukti dari berbagai pihak, dan sesuai dengan fakta yang ditemukan di lapangan. Namun Para Tergugat nyatanya tidak objektif. Hanya mengandalkan informasi atau bukti dari satu sumber, yaitu penyidik KPK. Akibatnya, dalam Laporan Audit Investigasi BPK 2017 hanya disajikan pandangan sepihak dari penyidik KPK.

Penelitian ini didasarkan pada rujukan beberapa penelitian sebelumnya, penelitian yang dilakukan oleh (Meutia Layli, 2020), (Muhammad Fathul Ihsan, 2018), menunjukan bahwa Kompetensi berpengaruh signifikan terhadap kualitas audit karena auditor harus memiliki keahlian, pengetahuan dan pengalaman audit agar menghasilkan kualitas audit yang baik. Namun tidak sejalan dengan penelitian yang dilakukan (Ayu Priyansari, 2014) menunjukan bahwa kompetensi tidak berpengaruh terhadap kualitas audit.

Penelitian yang dilakukan (Marlin Rusvitaniady, 2014) menunjukan bahwa Independensi berpengaruh positif terhadap kualitas audit, karena jika audior kehilangan independesinya, maka laporan audit yang dihasilkan tidak sesuai dengan kenyataan yang ada sehingga tidak dapat digunakan sebagai dasar pengambilan keputusan. Sedangkan berbeda dengan penelitian yang dilakukan (Meutia Layli, 2020) menyebut bahwa independensi tidak memiliki pengaruh terhadap kualitas audit.

Penelitian yang dilakukan oleh (Lestari \& Suryono, 2016) dan (Marlin Rusvitaniady, 2014) menunjukan bahwa objektivitas berpengaruh positif terhadap kualitas audit, karena semakin tinggi objektivitas maka semakin tinggi pula kualitas audit yang dihasilkan auditor. Berbeda dengan penelitian yang dilakukan oleh (Marlin Rusvitaniady, 2014) menyebut bahwa objektivitas tidak memiliki pengaruh signifikan terhadap kualitas audit.

\section{B. KAJIAN TEORI}

1. Kompetensi

a. Pengertian Kompetensi

Menururt Standar Pemeriksaan Keuangan Negara SPKN (2017) Tentang Pernyataan Standar Pemeriksaan 100 Standar Umum mengatakan bahwa Kompetensi adalah pendidikan, pengetahuan, pengalaman, dan keahlian yang dimiliki seseorang, baik tentang pemeriksaan maupun tentang hal-hal atau bidang tertentu.

Menurut (Arens, 2014) kompetensi adalah kemampuan individu untuk melaksanakan suatu pekerjaan dengan benar dan memiliki keunggulan yang berdasarkan pada hal-hal yang menyangkut pengetahuan keahlian dan sikap.

b. Pengukuran kompetensi

Menurut Standar Pemeriksaan Keuangan Negara (SPKN) (BPK-RI, 2017) Tentang Pernyataan Standar Pemeriksaan 100 Standar Umum menyatakan: Pemeriksa yang ditugaskan untuk melaksanakan Pemeriksaan menurut standar pemeriksaan harus secara kolektif memiliki kompetensi: 
1) latar belakang pendidikan, keahlian dan pengalaman, serta pengetahuan tentang standar pemeriksaan yang dapat diterapkan terhadap jenis pemeriksaan yang ditugaskan.

2) pengetahuan umum tentang lingkungan entitas, program dan kegiatan yang diperiksa (objek pemeriksaan).

3) keterampilan berkomunikasi secara jelas dan efektif, baik secara lisan maupun tulisan.

4) keterampilan yang memerlukan pengetahuan khusus dalam bidang tertentu sesuai dengan pemeriksaan yang dilaksanakan.

\section{Independensi}

a. Pengertian Independensi

Menurut Standar Pemeriksaan Keuangan Negara (SPKN) (BPK-RI, 2017) Tentang Pernyataan Standar Pemeriksaan 100 Standar Umum mengatakan bahwa Independensi adalah suatu sikap dan tindakan dalam melaksanakan pemeriksaan untuk tidak memihak dan dipandang tidak memihak kepada siapapun, serta tidak dipengaruhi dan dipandang tidak dipengaruhi oleh siapapun.

Menurut (Mulyadi, 2016) independensi adalah sikap mental yang bebas dari pengaruh, tidak dikendalikan oleh pihak lain. Tidak tergantung pada orang lain indenpendensi juga berarti adanya kejujuran dalam diri auditor dalam mempertimbngkan fakta dan adanya pertimbngan yang objektif tidak memihak dari auditor dalam merumuskan dan menyatakan pendapatnya.

\section{b. Pengukuran Independensi}

Menurut Standar Pemeriksaan Keuangan Negara (SPKN) (BPK-RI, 2017) Halaman 33 Tentang Pernyataan Standar Pemeriksaan 100 Standar Umum, variabel independensi dapat diukur dengan indikator gangguan pribadi dan gangguan ekstern.

\section{Objektivitas}

\section{a. Pengertian Objektivitas}

Menurut Standar Pemeriksaan Keuangan Negara (SPKN) (BPK-RI, 2017) Tentang Pernyataan Standar Pemeriksaan 300 Standar Umum, Objektivitas merupakan suatu sikap atau tindakan untuk tidak memihak dan bebas dari benturan kepentingan dalam menjalankan tugasnya.

Menurut (Mulyadi, 2016) Objektivitas adalah suatu kualitas yang memberikan nilai atas jasa yang diberikan anggota. Prinsip objektivitas mengharuskan anggota bersikap adil, tidak memihak, jujur secara intelektual, tidak berprasangka atau bias, serta bebas dari benturan kepentingan atau berada dibawah pengaruh pihak lain.

\section{b. Pengukuran Objektivitas}

Menurut Standar Pemeriksaan Keuangan Negara (SPKN) (BPK-RI, 2017)Halaman 63 Tentang Pernyataan Standar Pemeriksaan 300 Standar Umum, pemeriksa harus bersikap objektif dan harus mempertahankan hal - hal sebagai berikut:

1) Pemeriksa harus menyajikan Laporan Hasil Pemeriksaan (LHP) secara seimbang dan tidak memihak, dan

2) Pemeriksa harus menyajikan LHP sesuai dengan fakta yang ditemui di lapangan. 


\section{Kualitas Audit}

\section{a. Pengertian Kualitas Audit}

Menurut Standar Pemeriksaan Keuangan Negara (SPKN) (BPK-RI, 2017) Tentang Pernyataan Standar Pemeriksaan 100 Standar Umum mengatakan bahwa yang berkualitas akan bermanfaat bagi pengelolaan keuangan Negara yang lebih baik, akuntabel, transparan, ekonomis, efisien, dan efektif.

Menurut (Mulyadi, 2016) Kualitas audit didefinisikan sebagai jasa audit mencakup pemerolehan dan penilaiaan bukti yang mendasari laporan keuangan historis suatu entitas yang berisi asersi yang dibuat oleh manajemen entitas tersebut. Atas dasar audit yang dilaksanakan terhadap laporan keuangan historis suatu entitas auditor menyatakan suatu pendapat mengenai apakah laporan keuangan tersebut menyajikan secara wajar dalam suatu hal material, posisi keuangan dan hasil usaha entitas sesuai dengan prinsip akuntansi berterima umum.

\section{b. Pengukuran Kualitas Audit}

Menurut SPKN (standar pemeriksaan BPK 2017:12-77) dinyatakan dalam bentuk PSP standar pemeriksaan meliputi:

1) Standar Umum

2) Standar Pekerjaan Lapangan

3) Standar Pelaporan

\section{Kerangka Pemikiran}

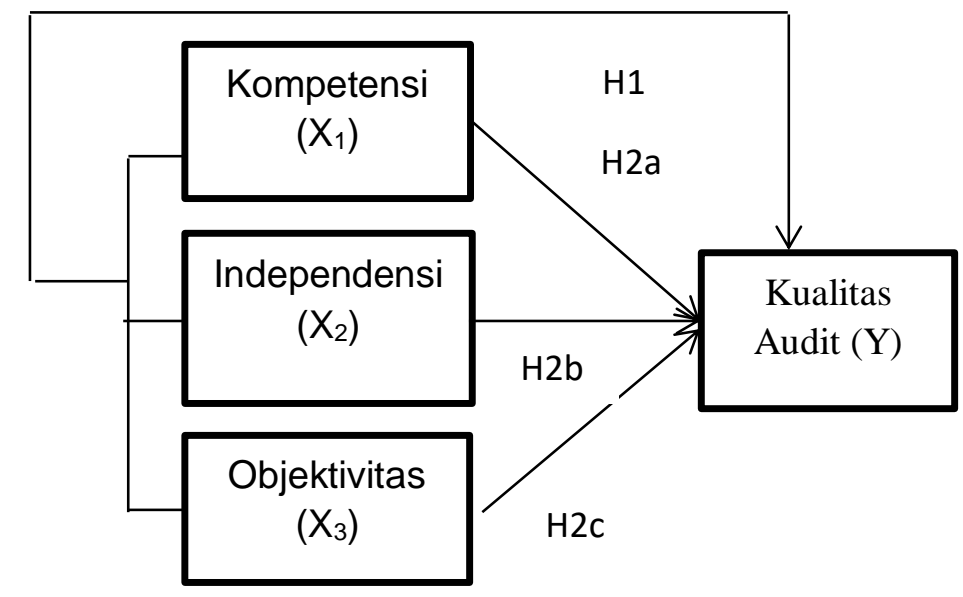

Sumber: penulis 2021

Kerangka pemikiran

\section{Hipotesis Penelitian}

Berdasarkan penjelasan kerangka, maka hipotesis penelitian diajukan sebagai jawaban sementara terhadap rumusan masalah penelitian ini adalah sebagai berikut: H1: Kompetensi, independensi dan objektivitas secara bersama berpengaruh terhadap kualitas audit.

$\mathrm{H} 2 \mathrm{a}$ : Kompetensi secara parsial berpengaruh terhadap kualitas audit

$\mathrm{H} 2 \mathrm{~b}$ : independensi secara parsial berpengaruh terhadap kualitas audit

$\mathrm{H} 2_{c}$ : Objektivitas secara parsial berpengaruh terhadap kualitas audit 


\section{METODE PENELITIAN}

Jenis penelitian yang akan digunakan penulis adalah penelitian asosiatif yang bertujuan untuk mengetahui pengaruh kompetensi $\left(X_{1}\right)$, indenpedensi $\left(X_{2}\right)$ dan objektivitas $\left(\mathrm{X}_{3}\right)$ terhadap kualitas audit $(\mathrm{Y})$. Lokasi penelitian dilakukan pada Badan Pemeriksa Keuangan (BPK) RI Perwakilan Provinsi Sumatera Selatan yang beralamatkan di Jl. Demang Lebar Daun No.2. Kec. Ilir barat 1 kota Palembang 30151 telp (7711) 410549.

Populasi yang akan diteliti adalah 35 auditor yang bekerja di Badan Pemeriksa Keuangan (BPK) RI Perwakilan Provinsi Sumatera Selatan, dengan menggunakan sampel jenuh karena seluruh populasi dijadikan sampel penelitian yang bertotalkan 35 orang auditor

Data yang digunakan dalam penelitian ini adalah data primer Data primer diperoleh dengan penyebaran kuesioner kepada responden yaitu auditor yang bekerja pada Kantor badan pemeriksa keuangan (BPK) RI perwakilan Provinsi sumatra selatan. Metode pengumpulan data yang digunakan dalam penelitian ini adalah Kuesioner dan wawancara. kuesioner yaitu dengan memberi pertanyaan langsung kepada auditor yang bekerja di kantor badan pemeriksa keuangan (BPK) RI perwakilan Provinsi Sumatra selatan.

Analisis data yang digunakan dalam penelitian ini adalah analisis kuantitatif dan kualitatif. Analisis kuantitatif dilakukan dengan menggunakan pengujian statistik dari hasil kuesioner, kemudian hasil pengujian tersebut dijelaskan dengan kalimatkalimat. Analisis kualitatif digunakan untuk melihat hasil kuesioner dengan menggunakan tabulasi dan dibantu dengan program for special science (SPSS).

Teknik analisis data dalam penelitian ini dibantu oleh statistical program for specience (SPSS). Sebelum melakukan analisis, sesuai dengan syarat metode OLS (ordinary least square) maka terlebih dahulu harus melakukan uji validitas, uji reliabilitas.

Selanjutnya uji asumsi klasik yang terdiri dari uji normalitas, uji multikolinearitas, uji heteroskedastisitas. setelah semua data dinyatakan normal, selanjutnya melakukan teknik analisis data yaitu analisis regresi linier berganda, analisis koefisien korelasi, analisis koefisien determinasi dan yang terakhir melakukan pengujian hipotesis yaitu uji $F$ (uji simultan) dan uji t (uji parsial).

\section{HASIL DAN PEMBAHASAN}

1. Uji Asumsi Klasik

a. Uji normalitas

Uji normalitas data digunakan untuk mengukur apakah data yang dimiliki berdistribusi normal sehingga dapat dipakai dalam ststistik. Hasil uji normalitas menggunakan program SPSS versi 25 dapat dilihat pada gambar berikut ini: 




Sumber: Hasil Output SPSS Versi 25, 2021

\section{Hasil Uji Normalitas Metode Grafik}

Berdasarkan gambar grafik normal P-plot terlihat titik menyebar disekitar garis diagonal dan penyebaran mengikuti arah diagonal, hal ini menunjukan bahwa model regresi layak dipakai karena memenuhi asumsi normalitas.

\section{b. Uji Multikolinearitas}

Uji multikolinieritas bertujuan untuk menguji apakah pada model regresi ditemukan korelasi antara variabel bebas. Hasil Uji multikolinieritas dapat dilihat pada tabel berikut:

Hasil Uji Multikolinieritas
\begin{tabular}{|l|r|r|}
\multicolumn{3}{|c|}{ Coefficients $^{\mathbf{a}}$} \\
\hline \multirow{3}{*}{ Model } & Collinearity Statistics \\
\cline { 2 - 3 } & Tolerance & \multicolumn{1}{c|}{ VIF } \\
\hline (Constant) & & \\
\hline KOMPETENSI & .473 & 2.116 \\
\hline INDEPENDENSI & .437 & 2.288 \\
\hline OBJEKTIVITAS & .656 & 1.524 \\
\hline a. Dependent Variable: KUALITAS AUDIT \\
\hline
\end{tabular} Sumber: Hasil Output SPSS Versi 25, 2021

Berdasarkan tabel diatas menunjukkan semua variabel bebas mempunyai nilai tolerance $>0,10$ dan nilai VIF $<10,0$ dengan demikian maka dapat disimpulkan bahwa seluruh variabel tidak terjadi multikoleniaritas.

\section{c. Uji Heteroskedastisitas}

Uji heteroskedastisitas dimaksudkan untuk menguji apakah dalam model regresi terjadi ketidaksamaan varians dari residual suatu pengamatan ke pengamatan lain. Hasil uji heteroskedastisitas terlihat pada gambar berikut: 


\section{Hasil Uji Heteroskedastisitas Pola Titik Pada Scatterrplot}

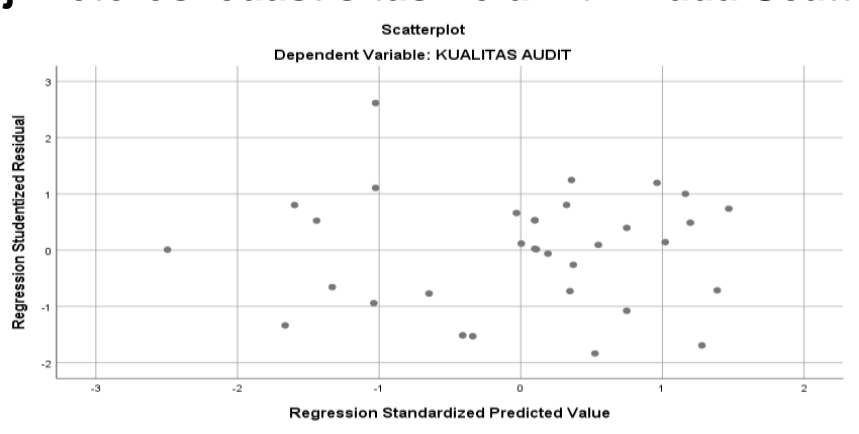

Sumber: Hasil Output SPSS Versi 25, 2021

Hasil uji heteroskedastisitas pada grafik di atas tidak ada pola yang jelas dan titik-titik menyebar diatas dan dibawah angka 0 pada sumbu $Y$, maka dapat disimpulkan bahwa tidak terjadinya heteroskedastisitas.

\section{Uji Analisis Data}

a. Uji Regresi Linear Berganda

Hasil Uji Linear Berganda

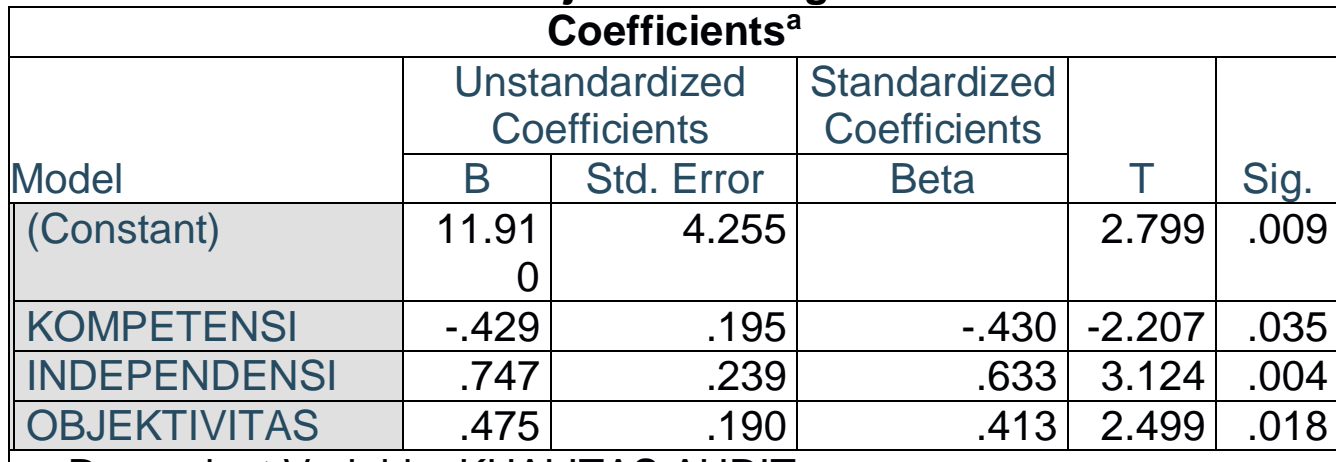

a. Dependent Variable: KUALITAS AUDIT

Sumber: Hasil Output SPSS Versi 25, 2021

Berdasarkan table di atas diperoleh hasil konstanta sebesar 11.910, variabel kompetensi $\left(X_{1}\right)$, sebesar - 0,429. Variabel independensi $\left(X_{2}\right)$, sebesar 0,747 dan variabel objektivitas $\left(X_{3}\right)$, sebesar 0,475 . Maka dapat dirumuskan persamaan regresi linear berganda sebagai berikut:

$Y=\alpha+\beta_{1} X_{1}+\beta_{2} X_{2}+\beta_{3} X_{3}+e$

$Y=11,910-0,429 X 1+0,747 X 2+0,475 X 3+e$

Dari persamaan regresi linear berganda yang terbentuk, dapat diinterprsentasikan sebagai berikut:

1) Nilai ( $\alpha$ ) yakni 11,910 artinya jika tidak terjadi perubahan variabel kompetensi, independensi dan objektivitas bernilai 0 , maka variabel kualitas audit $(Y)$ memiliki nilai sebesar 11,910 .

2) Nilai koefisien regresi kompetensi nilainya negatife sebesar -0,429 artinya jika variabel Kompetensi diturunkan satu satuan sedangkan variabel independen lain nilainya tetap maka tingkat kualitas audit mengalami penurunan sebesar 0,429. dan sebaliknya jika jika Kompetensi dinaikkan satu satuan sedangkan variabel independen lain nilainya tetap maka tingkat kualitas audit mengalami kenaikan sebesar 0,429. 
3) Nilai koefisien regresi independensi nilainya positif sebesar 0,747 artinya jika variabel independen dinaikkan satu satuan sedangkan variabel independen lain nilainya tetap maka tingkat kualitas audit mengalami kenaikan sebesar 0,747. Begitupun sebaliknya, jika independensi diturunkan satu satuan sedangkan variabel independen lain nilainya tetap maka tingkat kualitas audit mengalami penurunan sebesar 0,747

4) Nilai koefisien regresi objektivitas nilainya positif sebesar 0,475 artinya jika variabel variabel independen dinaikkan satu satuan sedangkan lain nilainya tetap maka tingkat kualitas audit mengalami kenaikan sebesar 0,475. Begitupun sebaliknya, jika Objektivitas diturunkan satu satuan sedangkan variabel independen lain nilainya tetap maka tingkat kualitas audit mengalami penurunan sebesar 0,475

\section{b. Uji Koefisien Determinan}

\section{Hasil Koefesien Determinasi $\left(\mathbf{R}^{2}\right)$}

\begin{tabular}{|l|r|r|r|c|}
\hline \multicolumn{7}{|c|}{ Model Summary $^{\mathbf{b}}$} \\
\hline Model & $\mathrm{R}$ & R Square & Adjusted R Square & $\begin{array}{c}\text { Std. Error of the } \\
\text { Estimate }\end{array}$ \\
\hline 1 & $.693^{\mathrm{a}}$ & .480 & .427 & 2.09131 \\
\hline \multicolumn{2}{|l}{ a. Predictors: (Constant), OBJEKTIVITAS, KOMPETENSI, INDEPENDENSI } \\
\hline
\end{tabular}

Sumber: Hasil Output SPSS Versi 25, 2021

Berdasarkan tabel diatas dapat dilihat bahwa nilai koefisien determinasi square $\left(R^{2}\right)$ sebesar 0,480 , nilai ini menunjukkan bahwa variabel Kualitas Audit dipengaruhi sebesar 48,0\% oleh variabel kompetensi, independensi dan objektivitas, sedangkan sisanya sebesar $52,0 \%$ dipengaruhi oleh variabel lain diluar penelitian ini seperti pengendalian internal, profesionalisme dan etika profesi.

\section{Uji Hipotesis}

\section{a. Uji Secara Bersama (F)}

Uji $\mathrm{F}$ dilakukan untuk mengetahui apakah pengaruh variabel kompetensi, independensi dan objektivitas terhadap kualitas audit secara bersama-sama atau simultan. Hasil uji hipotesis penelitian ini adalah sebagai berikut:

Hasil Uji bersama $(F)$

\begin{tabular}{|l|r|r|r|r|r|}
\hline \multicolumn{7}{|c|}{ ANOVA $^{\mathrm{a}}$} \\
\hline Model & $\begin{array}{c}\text { Sum of } \\
\text { Squares }\end{array}$ & \multicolumn{1}{|c|}{ Df } & $\begin{array}{c}\text { Mean } \\
\text { Square }\end{array}$ & \multicolumn{1}{c|}{ F } & Sig. \\
\hline Regression & 117.227 & 3 & 39.076 & 8.934 & $.000^{\mathrm{b}}$ \\
\hline Residual & 126.834 & 29 & 4.374 & & \\
\hline Total & 244.061 & 32 & & & \\
\hline a. Dependent Variable: KUALITAS AUDIT & & \\
\hline $\begin{array}{l}\text { b. Predictors: (Constant), OBJEKTIVITAS, KOMPETENSI, } \\
\text { INDEPENDENSI }\end{array}$
\end{tabular}

Sumber: Hasil Output SPSS Versi 25, 2021 
Berdasarkan tabel diatas, nilai signifikan $F$ menunjukkan bahwa Fhitung sebesar 8,934 > Ftabel sebesar 2,934 dengan tingkat signifikan 0,000 lebih kecil dari 0,05 . Hal ini menunjukkan bahwa kompetensi $\left(X_{1}\right)$, independensi $\left(X_{2}\right)$ dan objektivitas $\left(\mathrm{X}_{3}\right)$ berpengaruh dan signifikan terhadap kualitas audit $(\mathrm{Y})$.

\section{b. Uji Persial (t)}

Uji t dimaksudkan untuk menguji variabel-variabel bebas yaitu kompetensi, independensi dan objektivitas secara parsial/individu tarhadap variabel terkait, dengan hasil sebagai berikut:

\begin{tabular}{|c|c|c|c|c|c|}
\hline \multicolumn{6}{|c|}{ Hasil Uji Parsial (t) } \\
\hline \multicolumn{6}{|c|}{ Coefficients $^{\mathrm{a}}$} \\
\hline \multirow[b]{2}{*}{ Model } & \multicolumn{2}{|c|}{$\begin{array}{l}\text { Unstandardized } \\
\text { Coefficients }\end{array}$} & \multirow{2}{*}{$\begin{array}{c}\text { Standardized } \\
\text { Coefficients } \\
\text { Beta }\end{array}$} & \multirow[b]{2}{*}{$\mathrm{T}$} & \multirow[b]{2}{*}{ Sig. } \\
\hline & $\mathrm{B}$ & Std. Error & & & \\
\hline (Constant) & 11.910 & 4.255 & & 2.799 & .009 \\
\hline KOMPETENSI & -.429 & .195 & -.430 & -2.207 & .035 \\
\hline INDEPENDENSI & .747 & .239 & .633 & 3.124 & .004 \\
\hline OBJEKTIVITAS & .475 & .190 & .413 & 2.499 & .018 \\
\hline
\end{tabular}

a. Dependent Variable: KUALITAS AUDIT

Sumber: Hasil Output SPSS Versi 25, 2021

\section{H2a : Kompetensi Berpengaruh Terhadap Kualitas Audit}

Hasil uji hipotesis menunjukkan bahwa nilai thitung -2,207 sedangkan tabel 1,699 dapat disimpulkan bahwa $\mathrm{H}_{0} 2_{\mathrm{a}}$ ditolak dan $\mathrm{H}_{2} 2_{\mathrm{a}}$ diterima. serta nilai signifikan $0,035<$ 0,05 , maka kesimpulannya kompetensi $\left(X_{1}\right)$ berpengaruh negatif dan signifikan terhadap kualitas audit.

\section{$\mathbf{H} 2_{b}$ : Independensi Berpengaruh Terhadap Kualitas Audit}

Hasil uji hipotesis menunjukkan bahwa nilai thitung 3,124 sedangkan $t_{\text {tabel }} 1,669$ dapat disimpulkan bahwa $\mathrm{H}_{\circ} 2_{b}$ ditolak dan $\mathrm{H}_{a} 2_{b}$ diterima. serta nilai signifikan $0,004<$ 0,05 sehingga dapat disimpulkan variabel independensi $\left(X_{2}\right)$ berpengaruh positif dan signifikan terhadap kualitas audit.

\section{H2 : Objektivitas Berpengaruh Terhadap Kualitas Audit}

Hasil uji hipotesis menunjukkan bahwa nilai $t_{\text {hitung }} 2,499$ sedangkan $t_{\text {tabel }} 1,669$ dapat disimpulkan bahwa $\mathrm{H}_{0} 2_{c}$ ditolak dan $\mathrm{H}_{a} 2_{c}$ diterima. serta nilai signifikan $0,018<$ 0,05 sehingga dapat disimpulkan variabel objektivitas $\left(X_{3}\right)$ berpengaruh positif dan signifikan terhadap kualitas audit.

\section{Pengaruh Kompetensi, Independensi dan Objektivitas Terhadap Kualitas Audit}

Berdasarkan hasil uji hipotesis secara simultan menunjukkan bahwa $\mathrm{H}_{1}$ diterima artinya kompetensi $\left(X_{1}\right)$, independensi $\left(X_{2}\right)$ dan objektivitas $\left(X_{3}\right)$ berpengaruh signifikan terhadap kualitas audit $(Y)$. hal ini menunjukkan bahwa semakin tinggi kompetensi, independensi dan objektivitas maka semakin tinggi juga kualitas audit yang dihasilkan, artinya seorang auditor harus memiliki sikap yang kompeten independen dan objektif dalam melakukan audit, agar audit yang dihasilkan berkualitas. dalam menghasilkan laporan audit yang berkualitas seorang auditor harus memiliki keahlian, pengetahuan dan pengalaman dalam mengaudit laporan keuangan dan seorang auditor juga perlu memiliki sikap mental yang bebas dari 
pengaruh, tidak dikendalikan oleh pihak lain artinya seorang auditor harus jujur dan adil dalam mengaudit laporan keuangan agar laporan keuangan tersebut menjadi berkualitas.

Penelitian ini sejalan dengan penelitian yang dilakukan oleh (Marlin Rusvitaniady, 2014), (Ardita Aulia Rivani, 2018), menyatakan bahwa kompetensi independensi dan objektivitas berpengaruh signifikan terhadap kualitas audit. artinya semakin tinggi kompetensi, independensi dan objektivitas yang dimiliki seorang auditor BPK RI perwakilan Provinsi Sumatera Selatan, maka akan semakin tinggi pula kualitas audit yang dihasilkan. namun penelitian ini tidak sejalan dengan penelitian yang dilakukan oleh (Ayu Priyansari, 2014), (Ihya Adya Rahman, 2020) menyatakan bahwa kompetensi, independensi dan objektivitas tidak berpengaruh signifikan terhadap kualitas audit.

\section{Pengaruh Kompetensi terhadap kualitas audit.}

Berdasarkan hasil uji hipotesis secara persial menunjukkan bahwa $\mathrm{H}_{a}{ }_{2}$ diterima artinya kompetensi berpengaruh negatif dan signifikan terhadap kualitas audit. Hal ini menunjukkan bahwa semakin rendah kompetensi yang dimiliki oleh seorang auditor maka akan semakin rendah pula kualitas audit yang dihasilkan. Hal ini disebabkan walaupun seorang auditor yang berkompeten, kemungkinan auditor tidak menemukan kesalahan material dalam pemeriksaan masih bisa terjadi, komponen dari resiko ini sepenuhnya berada di bawah kontrol auditor, kemungkinan auditor tidak dapat menemukan kesalahan material disebabkan karena auditor pemeriksa tidak melakukan pemeriksaan dengan sepenuhnya. sehingga hasil laporan audit menjadi kurang baik.

Hasil penelitian ini sejalan dengan penelitian yang dilakukan (Meutia Layli, 2020), (Muhammad Fathul Ihsan, 2018), (Ardita Aulia Rivani, 2018), menunjukan bahwa Kompetensi berpengaruh signifikan terhadap kualitas audit. Semakin tinggi kompetensi auditor BPK RI perwakilan Provinsi Sumatera Selatan. maka semakin tinggi kualitas audit yang dihasilkan oleh auditor BPK RI perwakilan Provinsi Sumatera Selatan. Seorang auditor dapat menemukan dan melaporkan adanya pelanggaran dalam laporan keuangan yang dilakukan oleh pihak principal ditentukan oleh kualitas audit yang berpegang teguh terhadap pedoman Setandar Pemeriksaan Keuangan Negara SPKN yang telah ditetapkan, kompetensi auditor merupakan salah satu hal yang paling dasar yang harus dimiliki oleh seorang auditor, agar dapat menghasilkan laporan hasil audit yang berkualitas dan didukung oleh pengetahuan, keterampilan, pengalaman serta pendidikan. Sedangkan hasil ini tidak sejalan dengan penelitian (Nur Samsi, 2013),), (Ayu Priyansari, 2014) menunjukan bahwa kompetensi tidak berpengaruh signifikan terhadap kualitas audit.

\section{Pengaruh independensi terhadap kualitas audit}

Berdasarkan hasil uji hipotesis secara parsial menunjukkan bahwa $\mathrm{H}_{a} 2 \mathrm{~b}$ diterima artinya independensi berpengaruh signifikan terhadap kualitas audit. hal ini menunjukkan bahwa semakin tinggi independensi yang dimiliki oleh seorang auditor maka akan tinggi pula kualitas audit yang dihasilkan. Artinya seorang auditor yang memiliki sikap adil dan tindakan dalam melaksanakan pemeriksaan auditnya untuk tidak memihak kesiapapun, kejujuran dalam diri seorang auditor sangatlah penting didalam memeriksa laporan keuangan sehingga menghasilkan laporan audit yang berkualitas. 
Hasil penelitian ini sejalan dengan penelitian (Ayu Priyansari, 2014), (Marlin Rusvitaniady, 2014), (Reni Puji Lestari, 2016), (Muhammad Fathul Ihsan, 2018) menyatakan bahwa independensi berpengaruh signifikan terhadap kualitas audit. artinya semakin tinggi independensi auditor BPK RI perwakilan Provinsi Sumatera Selatan yang menunjukkan bahwa seorang pemeriksa harus bebas dari gangguan pribadi, ekstern maupun organisasi yang dapat mempengaruhi independensinya. Dengan independensi auditor akan bersikap untuk tidak memiliki kepentingan pribadi, tidak mudah dipengaruhi dan tidak memihak dalam memberikan kesimpulan. (Ardita Aulia Rivani, 2018). Penelitian ini tidak sejalan dengan penelitian yang dilakukan (Meutia Layli, 2020) menyatakan bahwa independensi tidak berpengaruh signifikan terhadap kualitas audit.

\section{Pengaruh objektivitas terhadap kualitas audit}

Berdasarkan hasil uji hipotesis secara parsial menunjukkan bahwa $\mathrm{H}_{a} 2_{c}$ diterima artinya objektivitas berpengaruh signifikan terhadap kualitas audit. Hal ini menunjukkan semakin tinggi objektivitas yang dimiliki oleh seorang auditor maka akan semakin tinggi pula kualitas audit yang dihasilkan. Artinya auditor yang professional dalam melaksanakan pekerjaannya dengan didukung adanya sikap objektivitas yang dimiliki oleh seorang auditor maka akan semakin meningkatkan kualitas audit yang dihasilkan. Oleh karena itu Seorang auditor dalam mengungkapkan suatu kondisi harus sesuai dengan fakta yang ada yaitu mengemukakan pendapat yang ada, tidak mencari kesalahan, serta menggunakan pikiran yang logis sehingga dapat menghasilkan laporan audit yang berkualitas.

Hasil penelitian ini didukung oleh penelitian (Reni Puji Lestari, 2016) menunjukan bahwa objektivitas berpengaruh signifikan terhadap kualitas audit, artinya semakin tinggi objektivitas auditor BPK RI perwakilan Provinsi Sumatera Selatan yang menunjukkan bahwa auditor yang professional dalam melaksanakan pekerjaan dengan didukung adanya sikap objektivitas yang dimiliki oleh seorang auditor, maka akan semakin meningkatkan kualitas audit yang dihasilkan begitu pula sebaliknya (Lestari \& Suryono, 2016). Penelitian ini tidak sejalan dengan penelitian yang dilakukan oleh (Linting, 2013) menyebutkan bahwa objektivitas tidak brpengaruh signifikan terhadap kualitas audit.

\section{E. KESIMPULAN}

Penelitian ini dilakukan untuk menguji dan untuk mengetahui bagaimanakah pengaruh kompetensi, independensi dan objektivitas terhadap kualitas audit, dari hasil penelitian dan pembahasan dapat disimpulkan sebagai berikut:

1. Kompetensi, independensi dan objektivitas secara simultan berpengaruh dan signifikan terhadap kualitas audit. Hal ini menunjukkan bahwa semakin tinggi kompetensi, independensi dan objektivitas yang dimiliki oleh seorang auditor maka akan semakin tinggi pula kualitas audit yang dihasilkan.

2. Kompetensi secara parsial berpengaruh negatif dan signifikan terhadap kualitas audit. Hal ini menunjukkan bahwa semakin tinggi kompetensi yang dimiliki oleh seorang auditor maka akan semakin rendah kualitas audit yang dihasilkan.

3. Independensi secara parsial berpengaruh signifikan terhadap kualitas audit. Hal ini menunjukkan bahwa semakin tinggi independensi yang dimiliki oleh seorang auditor maka akan semakin tinggi pula kualitas audit yang dihasilkan. 
4. Objektivitas secara parsial berpengaruh signifikan terhadap kualitas audit. Hal ini menunjukkan bahwa semakin tinggi objektivitas yang dimiliki oleh seorang auditor maka akan semakin tinggi pula kualitas audit yang dihasilkan.

Berdasarkan simpulan yang telah diuraikan maka saran yang dapat disimpulkan penulis adalah sebagai berikut:

1. Berdasarkan uji determinasi $\left(R^{2}\right)$ variabel kompetensi, independensi dan objektivitas sebesar $48,0 \%$ untuk penelitian selanjutnya diharapkan menggunakan variabel diluar penelitian ini seperti pengendalian internal, profrsionalisme dan etika profesi dan sebagainya yang dapat mempengaruhi kualitas audit.

2. Bagi peneliti selanjutnya, diharapkan untuk dapat memperluas wilayah cakup penelitian dan sebaiknya untuk refrensi peneltitian selanjutnya digunakan dengan jumlah sampel yang lebih besar agar hasilnya lebih maksimal.

\section{DAFTAR PUSTAKA}

Ardianingsih, r. (2018). Audit laporan keuangan. Jakarta: Bumi Aksara.

Ardita Aulia Rivani, D. N. (2018). Pengaruh Kompetensi, Independensi Dan Profesionalisme Terhadap Kualitas Audit (survey Pada Auditor Bpk Perwakilan Provinsi Jawa Barat). eProceedings of Management (pp. 34-37). Jakarta: Telkom University.

Arens, A. A. (2014). Auditing and Assurance Services An Integrated Approach 15th ed. Jakarta: Pearson .

Ayu Priyansari, N. T. (2014). Pengaruh Kompetensi, Independensi Dan Etika Auditor Terhadap Kualitas Audit. Retrieved Juli Kamis, 2021, from http://eprints.dinus.ac.id

BPK-RI. (2017). Standar Pemeriksaan Keuangan Negar. Jakarta: Badan Pemeriksa Keuangan Negara.

Hasibuan, O. (2019, Juli Kamis). Otto Hasibuan:Audit BPK soal Kerugian BLBI, Tak Independen. Retrieved Juni Rabu, 2020, from Liputan 6: https://www.liputan6.com/news/read/4009975/otto-hasibuan-audit-bpk-soalkerugian-blbi-tak-independen

IAPI. (2019, Juli Rabu). Calon Anggota BPK Tak Memiliki Kompetensi Auditor. Retrieved Juni Sabtu, 2021, from Bisnis.Tempo.co: https://bisnis.tempo.co/read/1222960/calon-anggota-bpk-tak-memilikikompetensi-auditor-iapi-kami-kecewa

Ihya Adya Rahman, S. P. (2020). Pengaruh Independensi Dan Objektivitas Auditor Terhadap Kualitas Audit (Study Empiris pada Auditor BPK RI Perwakilan DKI Jakarta). e-proceedings of management (p. 2907). Jakarta: Telkom University. 
Lestari, R. P., \& Suryono, B. P. (2016). Pengaruh Kompetensi, Independensi, Objektivitas dan Etika terhadap Kualitas Audit. Jurnal IImu dan Riset Akuntansi, 1-17.

Linting, I. (2013, 11 Minggu). Pengaruh Kompetensi, Objektivitas, Independensi, Dan Kinerja Auditor Internal Terhadap Kualitas Audit Pada Bri Inspektorat Makassar. Retrieved Desember Sabtu, 2021, from http://repository.unhas.ac.id/id/eprint/8945/

Marlin Rusvitaniady, D. P. (2014). engaruh Kompetensi, Independensi Auditor, Dan Objektivitas Terhadap Kualitas Audit (Studi Pada Auditor Bpk Ri Perwakilan Provinsi Jawa Barat). eProceedings of Management (pp. 1-14). Jakarta: Telkom Univercity .

Meutia Layli, J. A. (2020). Pengaruh Kompetensi, independensi dan Kemahiran Profesionel terhadap Kualitas Audit. Jurnal Perilaku dan Stategi Bisnis, 152158.

Muhammad Fathul Ihsan, M. M. (2018). Pengaruh Kompetensi, Independensi, Motivasi, dan Etika terhadap Kualitas Audit. Retrieved Agustus Sabtu, 2021, from digilib.unhas.ac.id: https://scholar.google.co.id/scholar?q=Pengaruh+kompetensi,+independensi, +motivasi+dan+etika+terhadap+kualitas+audit.+lhsan+(2018)\&hl=id\&as_sdt= 0\&as_vis $=1 \&$ oi $=$ scholart

Mulyadi. (2016). Sistem Informasi Akuntansi. Jakarta: Salemba Empat.

Nur Samsi, A. R. (2013). Pengaruh pengalaman kerja, independensi, dan kompetensi terhadap kualitas audit: Etika auditor sebagai variabel pemoderasi. Jurnal IImu dan Riset Akuntansi, 207-226.

Reni Puji Lestari, B. S. (2016). PENGARUH KOMPETENSI, INDEPENDENSI, OBJEKTIVITAS, DAN ETIKA TERHADAP KUALITAS AUDIT . Jurnal IImu dan Riset Akuntansi (JIRA), 1-17.

Tandiontong, M. (2016). Kualitas Audit dan Pengukurannya. Bandung: Alfabeta. 